\title{
Probable chronic renal failure caused by Lonomia caterpillar envenomation
}

\author{
Poliana Abrantes Schmitberger ${ }^{1}$, Tássia Clara Fernandes ${ }^{1}$, Robson Corrêa Santos ${ }^{1}$, Rafael Campos de Assis ${ }^{2}$, \\ Andréia Patrícia Gomes ${ }^{3}$, Priscila Karina Siqueira ${ }^{1}$, Rodrigo Roger Vitorino ${ }^{1}$, Eduardo Gomes de Mendonça ${ }^{3}$, \\ Maria Goreti de Almeida Oliveira ${ }^{3}$ and Rodrigo Siqueira-Batista ${ }^{3,4^{*}}$
}

\begin{abstract}
Erucism is a skin reaction to envenomation from certain poisonous caterpillar bristles. In Brazil, most reports of erucism provoked by Lonomia caterpillars are from the southern region. Most manifestations of erucism are local and include burning pain, itching, local hyperthermia and, rarely, blisters (benign symptoms with spontaneous regression in a few hours). General symptoms such as nausea and vomiting, headache, fever, myalgia, abdominal pain and conjunctivitis may also occur. Uncommon symptoms include arthritis, coagulation disorders (manifested as bruising and bleeding), intracerebral hemorrhage and acute renal failure, which comprise serious complications. The present study reports the case of 60-year-old patient from Rio de Janeiro state, Brazil, who came into contact with a caterpillar and developed, a few days later, chronic renal disease.
\end{abstract}

\section{Background}

Recently lepidopterans of the species Lonomia obliqua (order: Lepidoptera; family: Saturniidae) have been extensively studied due to the severe manifestations provoked by contact with their larval forms (caterpillars), such symptoms are known as erucism. These stinging caterpillars have bristles filled with toxins, which are able to cause lesions, blood and kidney disorders [1,2]. Two species are directly involved and may cause serious or fatal harm to humans, Lonomia obliqua and Lonomia achelous [2-6].

This article reports the case of patient who came into contact with a caterpillar and developed, a few days later, chronic renal disease.

\section{Case presentation and discussion}

A 60-year-old black man - born in the Rio de Janeiro city and living in Teresópolis, RJ, Brazil - reported that when he was taking the mail from his mailbox, he accidentally put his left arm on six specimens of light green and brown caterpillars, which had about $5 \mathrm{~cm}$ length. The animals were crushed by the arm of the man, who,

\footnotetext{
* Correspondence: rsbatista@ufv.br

${ }^{3}$ Universidade Federal de Viçosa (UFV), Viçosa, MG, Brasil

${ }^{4}$ Universidade Federal do Rio de Janeiro (UFRJ), Rio de Janeiro, RJ, Brasil Full list of author information is available at the end of the article
}

immediately, withdrawn it. He washed the arm using soap and water, applied alcohol to the affected area and also took an anti-allergy drug (could not say which).

The site affected by the caterpillars became swollen and after 20 minutes a burning sensation started. The victim also noticed a painful lymph node in the ipsilateral axilla, which disappeared spontaneously shortly after. In the same night, after dinner, he had abdominal distension associated with discomfort and vomiting. He did not take medicines to relieve the symptoms. As there was improvement, he laid down to sleep. After that, the man woke up at dawn feeling an intense abdominal pain (flank region) and arthralgia (upper and lower limbs), which became worse when he attempted to move.

Subsequently, the patient looked for medical assistance and went to a local hospital. His clinical picture was described as pain associated with sudden anuria. He was admitted to the hospital to treatment. The man reported a previous history of nephrolithiasis and received treatment with saline solution, analgesics and urinary catheter to provide relief. He also received treatment for arterial hypertension with atenolol, $50 \mathrm{mg} /$ day; until this time there was no evidence of kidney injury.

During the hospitalization, the patient had developed diffuse edema, flank pain and the anuria remained, despite of use of intravenous hydration and furosemide 
Table 1 Report of laboratory tests

\begin{tabular}{|c|c|c|c|c|c|c|}
\hline \multirow[t]{2}{*}{ Tests } & \multicolumn{5}{|c|}{ Hospitalization days } & \multirow[t]{2}{*}{ Benchmarks } \\
\hline & $4^{\text {th }}$ day & $7^{\text {th }}$ day & $10^{\text {th }}$ day & $14^{\text {th }}$ day & $16^{\text {th }}$ day & \\
\hline Leukocytes & 18.000 & 10.800 & - & 14.800 & - & $5.000-11.000 / \mathrm{mm}^{3}$ \\
\hline Basophils & 0 & 0 & - & 0 & - & $0-1 \%$ \\
\hline Eosinophils & 1 & 0 & - & 0 & - & $1-5 \%$ \\
\hline Myelocytes & 0 & 0 & - & 0 & - & $0 \%$ \\
\hline Metamyelocytes & 0 & 0 & - & 0 & - & $0 \%$ \\
\hline Neutrophil/Ban & 7 & 3 & - & 7 & - & $1-5 \%$ \\
\hline Neutrophil/Seg & - & 74 & - & 71 & - & $45-70 \%$ \\
\hline Lymphocytes & 14 & 21 & - & 19 & - & $20-45 \%$ \\
\hline Monocytes & 5 & 2 & - & 3 & - & $4-10 \%$ \\
\hline Erythrocyte & 3.83 & 2.79 & - & 2.8 & - & $3.80-5.20 \times 10^{4} / \mathrm{mm}^{3}$ \\
\hline Hematocrit & 34 & 24.6 & 24.4 & 25.9 & 27.7 & $36-50 \%$ \\
\hline MCV & 89 & 88.1 & 89.9 & - & - & 80-100 fL \\
\hline $\mathrm{MCH}$ & 30 & 30.3 & 29.8 & - & - & $28-32 p g$ \\
\hline Platelets & 154.000 & 111.000 & 148.000 & 278.000 & - & $150-400 \times 10^{3} / \mathrm{mm}^{3}$ \\
\hline$P R$ & - & - & $17.6^{\prime \prime}$ & $15.75^{\prime \prime}$ & - & $12.7-15.4^{\prime \prime}$ \\
\hline aPTा & - & - & $56^{\prime \prime}$ & $44^{\prime \prime}$ & - & 26.3-39.4" \\
\hline Sodium & 132 & 133 & 135 & 136 & - & $135-145$ mEq/L \\
\hline Potassium & 7.8 & 4.8 & 4.2 & 4.3 & - & $3.5-4.5 \mathrm{mEq} / \mathrm{L}$ \\
\hline Urea & 190 & 145 & 115 & 113 & 184 & $10-50 \mathrm{mg} / \mathrm{dL}$ \\
\hline Creatinine & 7.8 & 9.6 & 7.8 & 7.6 & 11.9 & $0.6-1.2 \mathrm{mg} / \mathrm{dL}$ \\
\hline ESR & - & 46 & - & - & - & up to $20 \mathrm{~mm} / \mathrm{h}$ \\
\hline$C T$ & - & $7^{\prime}$ & - & - & - & $5-10 \min$ \\
\hline BT & - & $1^{\prime}$ & - & - & - & $<7.1 \mathrm{~min}$ \\
\hline C-ANCA & - & Negative & - & - & - & Negative \\
\hline p-ANCA & - & Negative & - & - & - & Negative \\
\hline Blood glucose & - & 112 & - & 101 & - & $70-125 \mathrm{mg} / \mathrm{dL}$ \\
\hline
\end{tabular}

Source: patient's records.

$C T$ : coagulation time; $B T$ : bleeding time; ESR: erythrocyte sedimentation rate; $P R$ : prothrombin ratio; aPTT: activated partial thromboplastin time; $M C V$ : mean corpuscular volume; $M C H$ : mean corpuscular hemoglobin; $c-A N C A$ : cytoplasmic antineutrophil cytoplasmic antibodies; $p$-ANCA: perinuclear antineutrophil cytoplasmic antibodies.

infusion. Laboratory and imaging tests were performed (Tables 1 and 2).

After two more days, the patient was transferred to the Hospital das Clínicas de Teresópolis Costantino Ottaviano (HCTCO), where he remained for forty-five days due to hemodialysis treatment. Four days after the admission to HCTCO, he remembered the episode with

Table 2 Medical imaging tests

\begin{tabular}{cc}
\hline Test & Changes \\
\hline $\begin{array}{c}\text { Kidney and urinary } \\
\text { system ultrasonography } \\
\text { Computed tomography }\end{array}$ & Enlarged kidneys \\
& $\begin{array}{c}\text { Inflammatory infiltration of the perinephric } \\
\text { fat, uncomplicated renal calculus on the } \\
\text { right and a small amount of fluid in the pelvis }\end{array}$ \\
\hline
\end{tabular}

Source: patient's records. the caterpillars in the morning before the painful crisis and anuria. That was the moment when the suspicion of erucism by Lonomia aroused (seven days after the accident).

The use of SALon was not indicated because the patient did not meet the criteria for it, particularly due to the time elapsed since the accident, hospital care for more than 10 hours and less than or equal to 36 hours [1]. During the admission the patient showed bruises scattered on upper and lower limbs and two voluminous cases of melena. After those events, there was no spontaneous recovery of renal function, which progressed to chronic renal disease (CRD), stage $\mathrm{V}$ - end-stage renal disease, when the glomerular filtration rate is below $15 \%$ of normal and the patient needs, invariably, renal replacement therapy. 
Lonomia caterpillar has about six to seven centimeters long, and its color ranges from light brownish-green to yellowish-brown with three longitudinal stripes of darkbrown [4]. Its body is covered with bristles that contain toxins. The transformation to an adult moth occurs after a in ten weeks after three to six months of larval life $[7,8]$.

Lonomia is found throughout Brazil, however, numerous registered cases of erucism occurred in the southern region, mainly in Rio Grande do Sul and Santa Catarina states, and were attributed to L. obliqua $[9,10]$. In recent years, there have been accidents in Minas Gerais, Goiás, Maranhão and Rio de Janeiro states [1,4,7].

Erucism caused by Lonomia is uncommon in the state of Rio de Janeiro. Therefore, the present study is one of the first cases reported in the state. The increased rate of envenomations - especially in areas where they were not previously described - has been attributed to deforestation of indigenous trees, natural habitat of caterpillars, which are forced migrating to fruit trees in urban areas $[1,8]$.

The symptoms of Lonomia envenomation range from local cutaneous manifestations to serious and potentially fatal systemic reactions [11]. General symptoms such as headache, unspecific indisposition, fever, nausea, vomit, arthralgia, myalgia, conjunctivitis and abdominal pain vary depending on the species involved, the intensity of the contact and the victim's response $[7,8,12,13]$. Hemorrhagic syndrome and acute renal failure (ARF) are unusual outcomes, but potentially fatal [7,14-18].

The pathophysiological mechanisms of ARF in Lonomia envenomig are not clear yet. Probably, there is a relation between renal ischemia and systemic hypotension and/or fibrin deposition in glomerular capillaries [19-21]. Another hypothesis is that venom components may act directly on the kidneys [22,23].

Lonomia spp. venom is rich in several toxins that have procoagulant and fibrinolytic activities, which can significantly affect the blood coagulation process. For example, the enzyme lonofibrase is able to trigger a hemorrhagic syndrome similar to disseminated intravascular coagulation (DIC) by increasing fibrinogen degradation products and decreasing plasminogen, fibrinogen and factor XIII [1,5,17,24-26]. Lonomia obliqua venom contains several lipocalins (protein group that transports hydrophobic molecules), among which is the Lonomia obliqua prothrombin activator protein (Lopap), involved in the increase of expression of adhesion molecules on cellular surface [27-30].

Erucism is diagnosed based on history of contact with the caterpillar and corroborated by data from laboratory tests. Laboratory abnormalities include slightly low platelet count, high urea and creatinine levels, slight increase of total bilirubin, and augmentation of indirect bilirubin, free hemoglobin and haptoglobin decrease in cases of hemolysis [11].

Treatment consists of washing the affected area with cold water, cold compresses, local anesthetic infiltration using lidocaine $2 \%$ and topical corticosteroids. In case of bleeding, the patient should be kept resting in order to avoid traumatic intervention [5,11]. The antilonomic serum (SALon) is indicated according to the severity of the accident, and its early administration prevents bleeding manifestations that start from one to ten days after the contact depending on its intensity and location $[12,17,31-35]$.

\section{Conclusion}

The present study comprises an important report concerning the occurrence of Lonomia accidents in Rio de Janeiro, Brazil, a very uncommon situation in the area. This case also emphasizes the unusual progression of the envenomation to CRD, which, to the best of our knowledge, was not previously reported in the literature.

\section{Consent}

Informed consent was obtained from the patient for publication of this case report. The research project was submitted for analysis and approved by the UNIFESO Ethical Committee for research with human subjects (CEP), in accordance with Resolução 196/96 and Resolução 251-97 of the Brazilian National Health Council (Conselho Nacional de Saúde do Brasil).

\section{Abbreviations}

CRD: Chronic renal disease; ARF: Acute renal failure; DIC: Disseminated intravascular coagulation; SALon: Antilonomic serum.

\section{Competing interests}

The authors declare that there are no competing interests.

\section{Authors' contributions}

PAS, TCF, RCS and RCA described the case and drafted the first version of the article. APG, PKS, RRV, EGM, MGAO and RS-B made critical revision of the text. All authors read and approved the final manuscript.

\section{Author details}

${ }^{1}$ Centro Universitário Serra dos Órgãos (UNIFESO), Teresópolis, RJ, Brasil. ${ }^{2}$ Faculdade de Ciências Médicas e da Saúde de Juiz de Fora (SUPREMA), Juiz de Fora, MG, Brasil. ${ }^{3}$ Universidade Federal de Viçosa (UFV), Viçosa, MG, Brasil. ${ }^{4}$ Universidade Federal do Rio de Janeiro (UFRJ), Rio de Janeiro, RJ, Brasil.

Received: 30 January 2013 Accepted: 16 May 2013

Published: 3 June 2013

\section{References}

1. Correa MS, Siqueira-Batista R, Gomes AP, Franco-Barbosa A, Verzola ACA, Oliveira FRQ, Squeff FA, Motta-Leal-Filho JM, Tavares RH, Amorim DS, De-Maria-Moreira NL, Santos SS: Erucismo por Lonomia spp em Teresópolis, RJ, Brasil: relato de um caso provável e revisão da literatura. Rev Soc Bras Med Trop 2004, 37(5):418-421.

2. Brasil. Ministério da Saúde: Manual de diagnóstico e tratamento de acidentes por animais peçonhentos. $2^{a}$ edição. Brasília: Fundação Nacional de Saúde; 2001. 
3. Kowacs PA, Cardoso J, Entres M, Novak EM, Werneck LC: Fatal intracerebral hemorrhage secondary to Lonomia obliqua caterpillar envenoming: case report. Arq Neuropsiquiatr 2006, 64(4):1030-1032

4. Lisete ML, Corseuil E: Aspectos morfológicos de Lonomia obliqua walker (Lepidoptera: Saturniidae). Neotrop Entomol 2001, 30(3):373-378.

5. Veiga ABG: Caracterização molecular dos componentes do veneno de Lonomia obliqua: genes expressos e princípios ativos envolvidos nos distúrbios da coagulação e da fibrinólise, Dissertação de doutorado. Universidade Federal do Rio Grande do Sul; 2005 [http://www.lume.ufrgs.br/bitstream/ handle/10183/6566/000531846.pdf?sequence=1]

6. Instituto Butantan: Acidentes por animais peçonhentos. [http://www. butantan.gov.br]

7. Gamborgi GP: Insuficiência renal aguda em pacientes após acidente com lagarta da espécie - Lonomia obliqua, Dissertação de Mestrado.

Universidade Federal do Rio Grande do Sul; 2004 [http://www.lume.ufrgs.br/ handle/10183/7807].

8. Hossler EW: Caterpillars and moths - Part I. Dermatologic manifestations of encounters with Lepidoptera. J Am Acad Dermatol 2010, 62(1):1-10.

9. Garcia CM, Danni-Oliveira IM: Ocorrência de acidentes provocados por Lonomia obliqua Walker, no Estado do Paraná, no período de 1989 a 2001. Rev Soc Bras Med Trop 2007, 40(2):242-246.

10. Rubio GBG: Vigilância epidemiológica da distribuição da lagarta Lonomia obliqua Walker, 1855, no Estado do Paraná: Brasil. Rio de Janeiro. Cad Saúde Pública 2001, 17(4):1036.

11. Hossler EW: Caterpillars and moths. Dermatol Ther 2009, 22(4):353-366.

12. Centro de Informações Toxicológicas de Santa Catarina: Lonomia. ; 2008 [http://www.cit.sc.gov.br/index.php?p=monografias].

13. Bohrer CB, Reck Junior J, Fernandes D, Sordi R, Guimarães JA, Assreuy J, Termignoni C: Kallikrein-kinin system activation by Lonomia obliqua caterpillar bristles: involvement in edema and hypotension responses to envenomation. Toxicon 2007, 49(5):663-669.

14. Chudzinski-Tavassi AM, Carrijo-Carvalho LC: Biochemical and biological properties of Lonomia obliqua bristle extract. J Venom Anim Toxins ind Trop Dis 2006, 12(2):156-171.

15. Prezoto BC, Maffei FH, Mattar L, Chudzinski-Tavassi AM, Curi PR: Antithrombotic effect of Lonomia obliqua caterpillar bristle extract on experimental venous thrombosis. Braz J Med Biol Res 2002, 35(6):703-712

16. Berger $M$, Reck J Jr, Terra RM, Pinto AF, Termignoni C, Guimarães JA: Lonomia obliqua caterpillar envenomation causes platelet hypoaggregation and blood incoagulability in rats. Toxicon 2010, 55(1):33-44

17. Chan K, Lee A, Onell R, Etches W, Nahirniak S, Bagshaw SM, Larratt LM: Caterpillar-induced bleeding syndrome in a returning traveler. Canadian Med Assoc J 2008, 179(2):158-161.

18. Alvarez Flores MP, Zannin M, Chudzinski-Tavassi AM: New insight into the mechanism of Lonomia obliqua envenoming: toxin involvement and molecular approach. Pathophysiol Haemost Thromb 2010, 37(1):1-16.

19. Duarte CA, Caovilla J, Lorini I, Lorini D, Mantovani G, Sumida J, Manfre PC, Silveira RC, Moura SP: Insuficiência renal aguda por acidentes com lagartas. J Bras Nefrol 1990, 12(4):184-187.

20. Mendonça RZ, Greco KN, Sousa APB, Moraes RHP, Astray RM, Pereira CA: Enhancing effect of a protein from Lonomia obliqua hemolymph on recombinant protein production. Cytotechnology 2008, 57(1):83-91.

21. Pinto AF, Dragulev B, Guimarães JA, Fox JW: Novel perspectives on the pathogenesis of Lonomia obliqua caterpillar envenomation based on assessment of host response by gene expression analysis. Toxicon 2008, 51(6):1119-1128.

22. Abdulkader RC, Barbaro KC, Barros EJ, Burdmann EA: Nephrotoxicity of insect and spider venoms in Latin America. Semin Nephrol 2008, 28(4):373-382

23. Fan HW, Cardoso JLC, Olmos RD, Almeida FJ, Viana RP, Martinez APP: Síndrome hemorrágica e insuficiência renal aguda em uma mulher grávida após contato com lagartas Lonomia: relato de caso. Rev Inst Med Trop São Paulo 1998, 40(2):119-120.

24. Carrijo-Carvalho LC, Chudzinski-Tavassi AM: The venom of the Lonomia caterpillar: an overview. Toxicon 2007, 49(6):741-757.

25. Berger M, Reck J Jr, Terra RM, da Silva WO B, Santi L, Pinto AF, Vainstein MH, Termignoni C, Guimarães JÁ: Lonomia obliqua venomous secretion induces human platelet adhesion and aggregation. J Thromb Thrombolysis 2010, 30(3):300-310.
26. Siqueira-Batista R, Gomes P, Calixto-Lima L, Vitorino RR, Perez MCA, Mendonça EG, Oliveira MGA, Geller M: Sepse: atualidades e perspectivas. Rev Bras Ter Intensiva 2011, 23(2):207-216.

27. Lucena S, Guerrero B, Salazar AM, Gil A, Arocha-Piñango CL: Degradation of extracellular matrix proteins (fibronectin, vitronectin and laminin) by serine-proteinases isolated from Lonomia achelous caterpillar hemolymph. Blood Coagul Fibrinolysis 2006, 17(6):427-435.

28. Reis CV, Andrade SA, Ramos OH, Ramos CR, Ho PL, Batista IF, Chudzinski-Tavassi AM: Lopap, a prothrombin activator from Lonomia obliqua belonging to the lipocalin family: recombinant production, biochemical characterization and structure-function insights. Biochem J 2006, 398(Pt2):295-302.

29. Seibert CS, Santoro ML, Tambourgi DV, Sampaio SC, Takahashi HK, Peres CM, Curi R, Sano-Martins IS: Lonomia obliqua (Lepidoptera, Saturniidae) caterpillar bristle extract induces direct lysis by cleaving erythrocyte membrane glycoproteins. Toxicon 2010, 55(7):1323-1330.

30. Carrijo-Carvalho LC, Maria DA, Ventura JS, Morais KLP, Melo RL, Rodrigues CJ, Chudzinski-Tavassi AM: A lipocalin-derived peptide modulating fibroblasts and extracellular matrix proteins. J Toxicol 2012 [http://www. hindawi.com/journals/jt/2012/325250/].

31. Walter GM: Acidente com Lonomia: tratamento com soro antilonômico e insuficiência renal aguda, Tese de Mestrado. Universidade Federal do Rio Grande do Sul; 1999 [http://www.lume.ufrgs.br/handle/10183/26141].

32. Pinto AF, Berger M, Reck J Jr, Terra RM, Guimarães JA: Lonomia obliqua venom: In vivo effects and molecular aspects associated with the hemorrhagic syndrome. Toxicon 2010, 56(7):1103-1112.

33. Arocha-Piñango CL, Guerrero B: Lonomia genus caterpillar envenomation: clinical and biological aspects. Haemostasis 2001, 31(3-6):288-293.

34. Centro de Informação Toxicológica do Rio Grande do Sul: Manual de Diagnóstico e Tratamento de Acidentes por Lonomia; 1999 [http://www. bvsde.paho.org/bvstox/p/fulltext/lonomia/lonomia.pdf].

35. Gonçalves LR, Sousa-e-Silva MC, Tomy SC, Sano-Martins IS: Efficacy of serum therapy on the treatment of rats experimentally envenomed by bristle extract of the caterpillar Lonomia obliqua: comparison to epsilon-aminocaproic acid therapy. Toxicon 2007, 50(3):349-356.

doi:10.1186/1678-9199-19-14

Cite this article as: Schmitberger et al:: Probable chronic renal failure caused by Lonomia caterpillar envenomation. Journal of Venomous Animals and Toxins including Tropical Diseases 2013 19:14.

\section{Submit your next manuscript to BioMed Central and take full advantage of:}

- Convenient online submission

- Thorough peer review

- No space constraints or color figure charges

- Immediate publication on acceptance

- Inclusion in PubMed, CAS, Scopus and Google Scholar

- Research which is freely available for redistribution 